\title{
Hearing loss in Africa: current genetic profile
}

\author{
Samuel Mawuli Adadey ${ }^{1,2} \cdot$ Edmond Wonkam-Tingang $^{2} \cdot$ Elvis Twumasi Aboagye $^{1} \cdot$ Osbourne Quaye $^{1}$. \\ Gordon A. Awandare ${ }^{1} \cdot$ Ambroise Wonkam ${ }^{2}$ (I)
}

Received: 31 May 2021 / Accepted: 21 September 2021 / Published online: 5 October 2021

(c) The Author(s) 2021

\begin{abstract}
Hearing impairment (HI) is highly heterogeneous with over 123 associated genes reported to date, mostly from studies among Europeans and Asians. Here, we performed a systematic review of literature on the genetic profile of HI in Africa. The study protocol was registered on PROSPERO, International Prospective Register of Systematic Reviews with the registration number "CRD42021240852". Literature search was conducted on PubMed, Scopus, Africa-Wide Information, and Web of Science databases. A total of 89 full-text records was selected and retrieved for data extraction and analyses. We found reports from only 17/54 (31.5\%) African countries. The majority $(61 / 89 ; 68.5 \%)$ of articles were from North Africa, with few reports found from sub-Saharan Africa. The most common method used in these publications was targeted gene sequencing $(n=66 / 111 ; 59.5 \%)$, and only $13.5 \%(n=15 / 111)$ used whole-exome sequencing. More than half of the studies were performed in families segregating $\mathrm{HI}(n=51 / 89)$. GJB2 was the most investigated gene, with GJB2: p.(R143W) founder variant only reported in Ghana, while GJB2: c.35delG was common in North African countries. Variants in MYO15A were the second frequently reported in both North and Central Africa, followed by ATP6V1B1 only reported from North Africa. Usher syndrome was the main syndromic HI molecularly investigated, with variants in five genes reported: USH2A, USHIG, USH1C, MYO7A, and PCDH15. MYO7A: p.(P1780S) founder variant was reported as the common Usher syndrome variant among Black South Africans. This review provides the most comprehensive data on HI gene variants in the largely underinvestigated African populations. Future exomes studies particularly in multiplex families will likely provide opportunities for the discovery of the next sets of novel HI genes, and well as unreported variants in known genes to further our understanding of HI pathobiology, globally.
\end{abstract}

\section{Introduction}

Hearing impairment (HI) is the most prevalent sensory disability with a growing concern globally (Mulwafu et al. 2016; Olusanya et al. 2014). The World Health Organisation's (WHO) estimates of the number of people living with disabling HI globally increased from 278 million in 2005, to 360 million in 2012, and 466 million in 2018 (6.1\% of the world population) (Mulwafu et al. 2016). Based on the WHO projections, 2.5 billion people would have some form of $\mathrm{HI}$

Ambroise Wonkam

ambroise.wonkam@uct.ac.za

1 Department of Biochemistry, Cell and Molecular Biology, West African Centre for Cell Biology of Infectious Pathogens (WACCBIP), University of Ghana, P.O. Box LG 54, Legon, Accra, Ghana

2 Division of Human Genetics, Faculty of Health Sciences, University of Cape Town, Anzio Road, Observatory, Cape Town 7925, South Africa by 2050 . HI is higher in sub-Saharan Africa, as it occurs in 6 per 1000 live births as compared to a lower incidence of 1 per 1000 live births in high-income countries (Olusanya et al. 2014). Depending on its pathophysiology, HI can be conductive (resulting from abnormalities of the external ear and/or the ossicles of the middle ear), sensorineural (results from a malfunction of inner ear structures), or mixed (a combination of conductive and sensorineural HI) (Shearer et al. 2017). The etiologies of HI vary from genetic to environmental factors, while some HI cases have an unknown cause (Wonkam Tingang et al. 2020a; Wonkam et al. 2019). Genetic factors contribute to $30-50 \%$ of HI cases of childhood HI in sub-Saharan Africa (Lebeko et al. 2015). HI of genetic origin may be syndromic, where there are other clinical features associated with the loss of hearing. Conversely, $\mathrm{HI}$ may be non-syndromic whereby $\mathrm{HI}$ is the only observed clinical feature (Lebeko et al. 2015).

Syndromic HI accounts for up to $30 \%$ of hereditary HI and over 400 syndromes associated with HI have been 
described to date, including Waardenburg syndrome, Branchiootorenal syndrome, Usher syndrome, Pendred syndrome, Keratitis-ichthyosis-deafness syndrome, and Alport syndrome (Bayazit and Yilmaz 2006; Lebeko et al. 2015; Shearer et al. 2017). Non-syndromic HI (NSHI) accounts for approximately $70 \%$ of all hereditary $\mathrm{Hl}$ cases (Bayazit and Y1lmaz 2006; Shearer et al. 2017). The inheritance pattern among neonates with NSHI is approximately $80 \%$ inherited as autosomal recessive, about $20 \%$ autosomal dominant, and $<1 \% \mathrm{X}$-linked or mitochondrial (Shearer et al. 2017; Smith et al. 2005). NSHI is highly genetically heterogeneous, with approximately 170 loci and 123 genes identified to date (Van Camp and Smith 2006). The most common variants associated with autosomal recessive non-syndromic HI (ARNSHI) have been found within the connexin genes, and they have been prevalent among European, and Asian populations (Lebeko et al. 2015). Connexins were shown to be expressed in the inner ear, and some studies support their role in the metabolism of potassium and nutrient in the cochlea (Adadey et al. 2020b; Xu and Nicholson 2013).

GJB2 (on chromosome 13q12) is the most common connexin gene associated with ARNSHL in European and Asian populations accounting for almost $50 \%$ of cases (Adadey et al. 2020b; Bayazit and Yilmaz 2006). The most common $G J B 2$ variant is c. $35 \mathrm{delG}$ which is seen in up to $70 \%$ of cases. GJB2 c.35delG is prevalent throughout Europe, North Africa, and the Middle East, as well as areas populated largely by immigrants from these regions (Bayazit and Yilmaz 2006; Lebeko et al. 2015). Other GJB2 variants are prevalent in specific populations, including c.235delC among Asians, p.W24X in Indians, 167delT among Ashkenazi Jews, and p.R143W in Africans from Ghana (Adadey et al. 2020b; Brobby et al. 1998; Chan and Chang 2014). Apart from connexin genes, other common genes implicated in $\mathrm{HI}$ among European and Asian populations include SLC26A4 (implicated in Cochlear Homeostasis), MYO15A (involved in Cellular Organization), OTOF (involved in Neural transmission), TMC1, CDH23 (implicated in Cellular Organization), and TMPRSS3 (Duman and Tekin 2012).

The patterns of variations in African populations, the much diverse in the world, are shaped by ancestry reasons with Africans being the oldest human population, intra-African and out and back to Africa migration dynamics associated with population admixture, and ecological reasons with the north-south axis of the African continent that is associated with drastic differences in climate, diet, and exposure to infectious disease, all of which are motor of natural genomic selections (Wonkam 2021). Genetic variations of African populations have suggested three major divisions of the continent: (1) Mediterranean North Africa, (2) subSaharan Middle, West, and East Africa, and (3) southern regions of Africa (Campbell and Tishkoff 2008; Reed and Tishkoff 2006). Moreover, population genetic analysis using geographically, and ethnically diverse Africans indicated that there are over 13 genetically distinct populations and high levels of population admixture in Africa (Campbell and Tishkoff 2008), which will favour the much-needed discovery of new HI genes in order to improve diagnosis and care in Africa and globally (Chakchouk et al. 2019; Lebeko et al. 2016, 2017).

Although there are HI genetic studies from Africa, with the majority from the Mediterranean north African populations, the genetic etiology of $\mathrm{HI}$ in most African populations remains elusive. Indeed, apart from the report in Ghana, pathogenic or likely pathogenic (PLP) variants in GJB2 do not seem to contribute much to NSHI in most sub-Sahara African populations (Wonkam Tingang et al. 2020). Besides, targeted sequencing panels (with over $100 \mathrm{HI}$ genes) have detected a consistently lower rate of pathogenic and likely pathogenic (PLP) variants in sporadic HI cases of African ancestry e.g. African Americans (26\%), and Nigerians and Black South Africans (4\%), compared to $>70 \%$ for Europeans and Asians (Sloan-Heggen et al. 2016; Yan et al. 2016). Therefore, there is an urgent need to investigate the genetic etiologies of $\mathrm{HI}$ across Africa, to improve our knowledge of variants and genes that contribute to $\mathrm{HI}$ in these populations. The present review provides the current state of knowledge on the genetics of hereditary $\mathrm{HI}$ in Africa.

\section{Methods}

\section{Search strategy and data extraction}

The keywords: hearing impairment, genetics/genomics, diagnosis, and Africa were used to develop the search term "Hearing Impairment" OR "Hearing loss" OR "Deafness") AND ("Genetics" OR "Genomics") AND ("Testing" OR "Screening" OR "Diagnosis") AND "Africa". The search was conducted by two independent reviewers on PubMed, Scopus, Africa-Wide Information, and Web of Science databases (Fig. 1). The search was conducted between 1st to 14th March 2021. We registered the protocol on PROSPERO, International Prospective Register of Systematic Reviews with the registration number "CRD42021240852".

To remove any form of bias, the data extraction was conducted by two independent reviewers (SMA and ETW) using structured data extraction Microsoft Excel spreadsheets (Office 365 education license under the University of Cape Town, South Africa). Based on the inclusion/exclusion criteria outlined below, data was extracted from 89 full-length publications out of 182 screened. The data extraction form consisted of the following data points (1) name of first and corresponding authors, (2) date of publication, (3) population investigated (4) total number of affected people investigated, (5) gene under investigation, (6) number of reported 
Fig. 1 Flow diagram showing the screening process of records

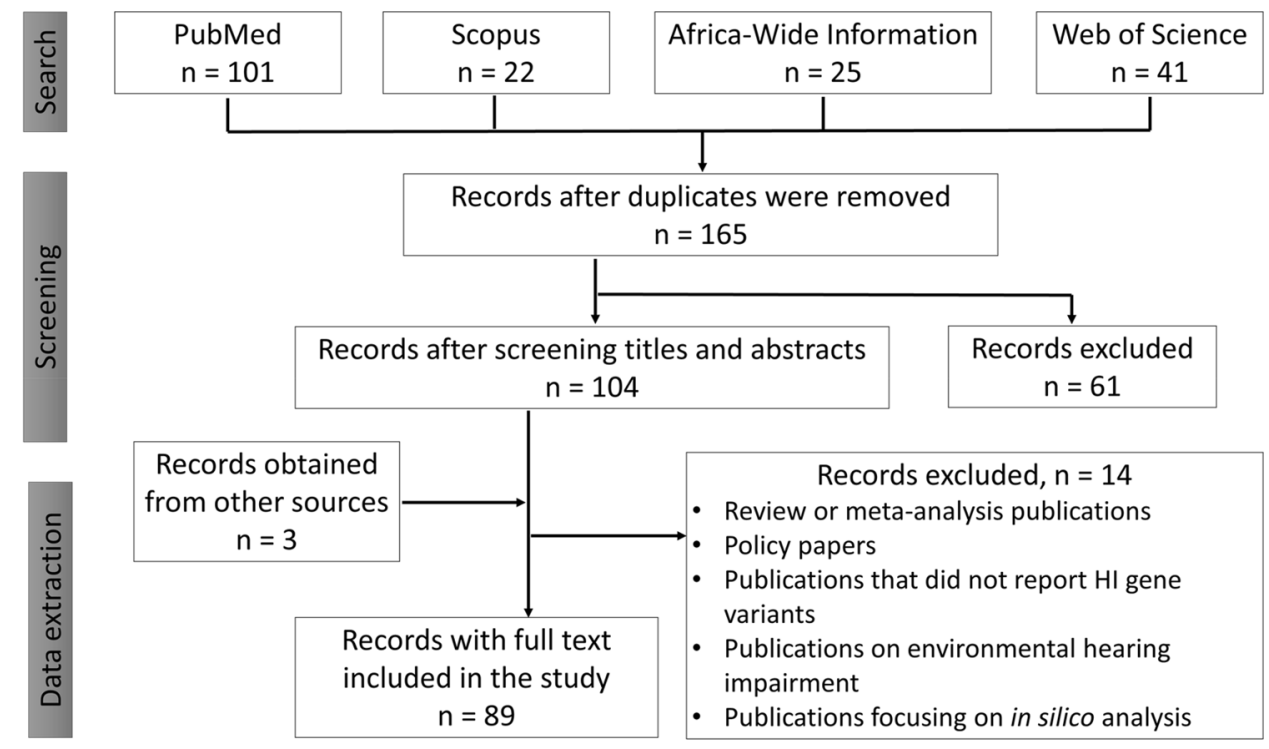

mutant alleles per variant. An expert in the field of genetics and HI (AW) was consulted whenever there was a disagreement between the judgment of the two reviewers. The extracted data were imported into SPSS version 25 (IBM, Armonk, New York, United States) and analyzed.

\section{Inclusion criteria}

- Publications from Africa on hearing impairment

- Publications on genetics/genomics of hearing impairment

- Full-length articles.

\section{Exclusion criteria}

- Review or meta-analysis publications

- Policy papers

- Publications that did not report HI gene variants

- Publications on environmental hearing impairment

- Publications focusing on in silico analysis.

\section{Quality assessment}

The quality of the documents reviewed was assessed by independent reviewers (SMA and EWT) prior to data extraction. The quality was assessment was conducted using the quality of genetic studies (Q-Genie) tool developed by Sohani et al. (2016). The tool designed by Hoy et al. (2012) was used to assess the risk of bias for the prevalence studies. By discussion and consensus, and sometimes with the consultation of an expert in the field (AW), discrepancies and differences in the judgment of the reviewers (SMA and EWT) were resolved.

\section{Clinical significance assessment of variants}

The clinical significance was assessed for the identified variants on 3 variant databases; InterVar (Li and Wang 2017), VarSome (Kopanos et al. 2019), and ClinVar (Landrum et al. 2020). VarSome and InterVar were tools used for assessing the clinical significance of variants based on the American College of Medical Genetics and Genomics (ACMG)/Association for Molecular Pathology (AMP) 2015 guidelines (Li and Wang 2017). In addition, ClinVar Strong was used to provide further evidence of the clinical significance of the variants.

\section{Results}

A total of 189 records were retrieved from the various databases searched, 25 retrieved from Africa Wide Information, 101 from PubMed, 22 from Scopus, and 41 from Web of Science. The retrieved records were combined, and duplicates were removed. The titles of the retrieved documents were used for the first level screening followed by the abstracts and 89 records were included in the study (Fig. 1). The 89 publications considered for the review dated from 1998 to 2021 with, a slowly increasing trend in publication numbers (Figure S1A). The geographical representation of published records (Figure S1B) showed that most HI studies were conducted in Northern Africa (61/89; 68.5\%), with Tunisia accounting for a third of publications $(28 / 89$; $31.5 \%)$.

Considering families with two or more affected members as familial cases, we observed that a slightly higher number was recorded for publications that focused on familial cases $(41 ; 46.1 \%$ publications $)$, compared to 
A

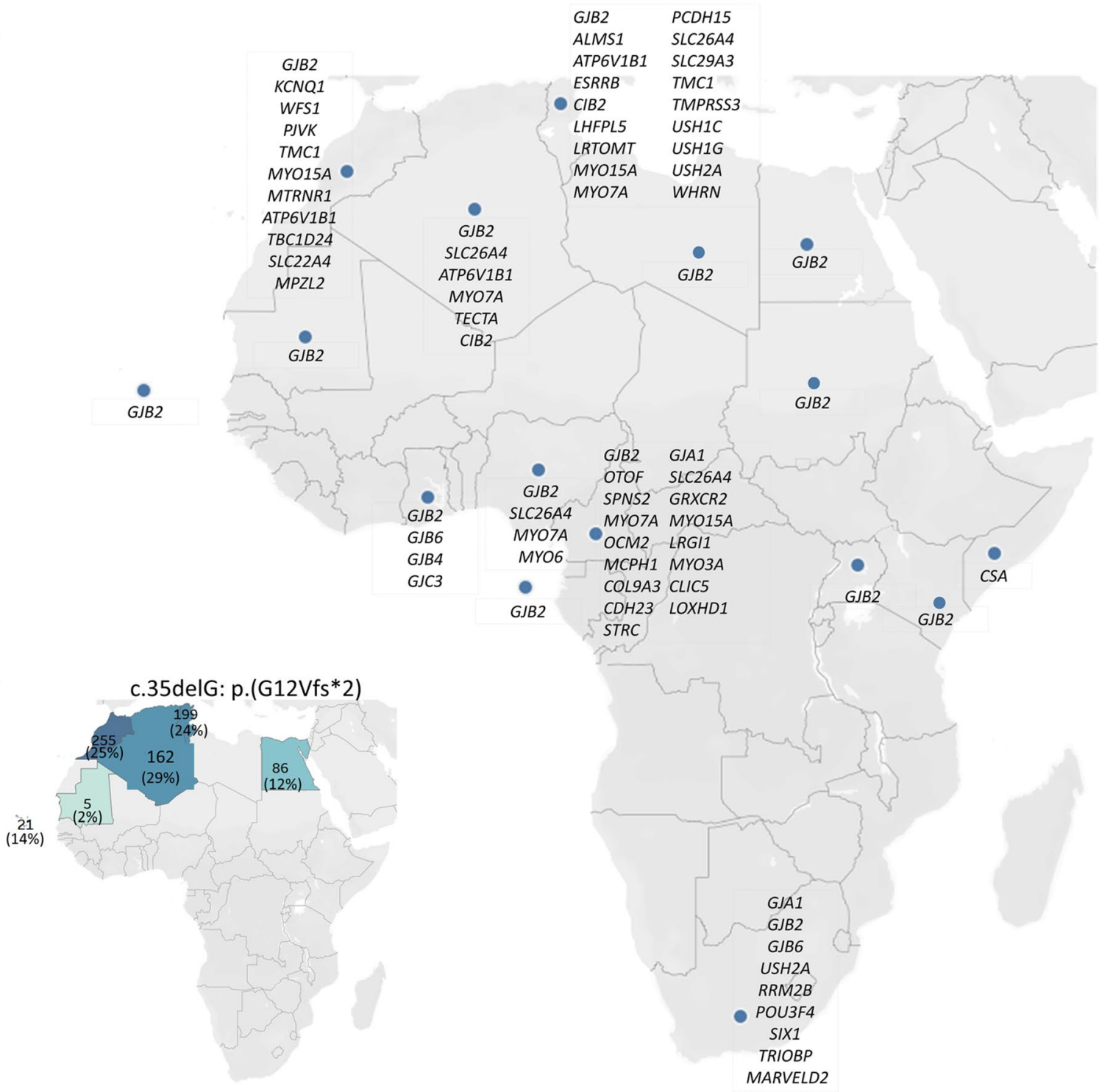

B

D c.139G >T: p. $\left(E 47^{*}\right)$

C c.427C >T: p.(R143W)

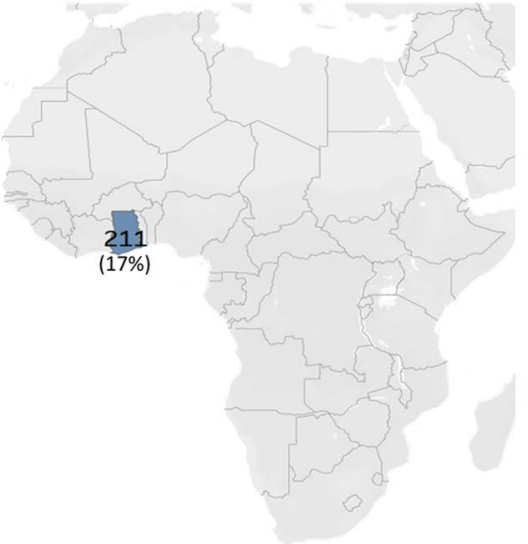

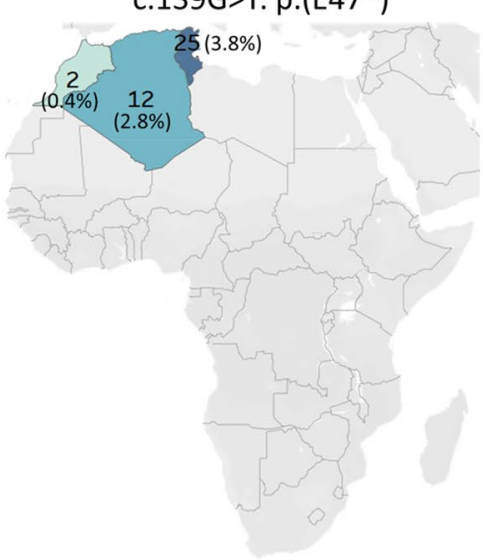

E c.109G>A: p.(V37I)

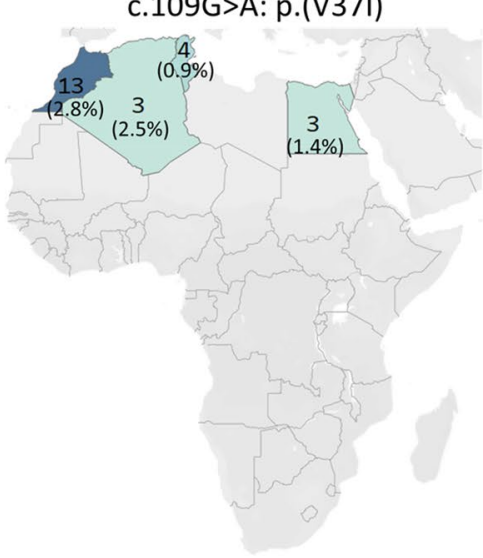


४Fig. 2 Geographical distribution of HI genes in Africa. A A geographical plot of the genes reported from different African countries. The geographical distribution of four common $G J B 2$ variants reported in Africa: B GJB2: c.35delG: p.(G12Vfs*2), C GJB2: c.427C >T: p.(R143W), D GJB2: c.139G>T: p.(E47*), E GJB2: c.109G >A: p.(V37I). The total number of mutant alleles (allele frequency in percentages) per country was displayed on the map

non-familial cases (36 publications, 40.5\%) (Figure S2A). Ten $(11.2 \%)$ publications report on both familial and nonfamilial cases while two (2.2\%) publications investigated $\mathrm{HI}$ genes in hearing controls. The majority of familial studies reported on one to five familial cases (20 publications), while 13 publications reported on 51-99 familial cases (Figure S2B). Only 5 publications reported on more than 99 familial cases. Northern African countries were found to report the highest percentage of consanguineous families with Tunisia having the highest number of publications (22/89 studies) that reported on consanguineous families (Figure S1B).

\section{Hearing impairment genes in Africa}

The analysis of the retrieved data showed a heterogeneous nature of HI genes in Africa with $46 \mathrm{HI}$ genes reported from 17 African countries (Fig. 2A), with most studies on GJB2 which was reported in 76.5\% (13/17) of the countries. From the studies conducted in Tunisia, the country with the highest number of publications, $18 \mathrm{HI}$ genes were found. Cameroon, with 17 genes and emerging as the second country with a description of variants in numerous genes.

\section{Molecular methods reported}

This review identified more than 15 molecular methods used to investigate $\mathrm{HI}$ gene variants. Targeted genes sequencing was the most used method in Africa $(n=66 / 111 ; 59.5 \%)$ followed by exome sequencing $(n=15 / 111 ; 13.5 \%)$. Only five studies combined exome sequencing techniques with targeted sequencing. Two studies used specifically designed North African Deafness Chip (Table S1). Nineteen out of the 89 studies $(21.3 \%)$ were found to use combinations of more than one method to screen for HI genes, which mostly consisted of restriction fragment length polymorphism (RFLP)-PCR combined with Sanger sequencing or targeted sequencing combined with exome sequencing. None of the studies reviewed used whole-genome sequencing (Table S1). It is worth noting that the studies found in some countries (Kenya, Mauritania, São Tomé and Príncipe, Somalia, Sudan, and Uganda) used only targeted sequencing which is effective but not comprehensive (Table S1).

\section{Connexin genes}

\section{Connexin 26 (GJB2) variants}

We identified 28 PLP variants in GJB2 gene (Table S2), of which c.35delG was the most associated variant (Table S3). The top four GJB2 variants (variants with more than 20 reported alleles) were found to be c.35delG (728/3544 alleles, 20.5\%), p.(R143W) (211/1230 alleles, 17.2\%), p.(E47*) (39/1552 alleles, $2.5 \%)$, and p.(V37I) $(23 / 1260$ alleles, $1.8 \%$ ). The rest 22 GJB2 variants had less than 20 reported alleles (Table S3). GJB2: c.35delG: p.(G12Vfs*2) was reported only in the Northern African countries with most cases from Morocco. Similarly, GJB2: c.139G $>$ T: p. $\left(\mathrm{E} 47^{*}\right)$ and c.109G $>$ A: p.(V37I) variants were common in North African countries but not sub-Saharan African countries. Ghana was the only African country with a report of high-frequency GJB2: c.427C $>\mathrm{T}$ : p.(R143W) founder variant (Fig. 2). There were studies from some sub-Saharan African countries such as Cameroon and South Africa that extensively investigated $\mathrm{HI}$ genes but did not record any significant contribution of $G J B 2$ variants to HI. One of such studies from Cameroon reported a variant of uncertain significance [GJB2: c.499G >A (p.V167M)] in the heterozygous state in an affected family (Wonkam et al. 2019).

\section{GJA1 and GJB4 variants}

GJA1 (connexin 43) may not contribute to HI in Africa. However, benign and VUS variants were reported from South Africa and Cameroon (Table S4). In Ghana, seven variants in GJB4 (connexin 30.3) were reported however, all except one were either benign or uncertain significance. A likely pathogenic GJB4 variant [p.(N119T): c.356A>C] was reported in a non-familial case from Ghana (Table S4).

\section{Non-connexin NSHI gene variants}

Except for connexin genes, 34 NSHI gene variants were identified from 7 countries: Algeria (Behlouli et al. 2016; Talbi et al. 2018), Cameroon (Lebeko et al. 2016; Wonkam-Tingang et al. 2020b, 2021; Wonkam et al. 2021a, b), Ghana (Adadey et al. 2021), Morocco (Amalou et al. 2021; Bakhchane et al. 2015a; Ebermann et al. 2007), Nigeria (Yan et al. 2016), South Africa (Yan et al. 2016), Tunisia (Souissi et al. 2021; Belguith et al. 2009; Bensaid et al. 2011; Chakchouk et al. 2015; Chiereghin et al. 2021; Tlili et al. 2005, 2008; Masmoudi et al. 2001). Tunisia recorded the highest number of NSHI genes with PLP variants (11/34). PLP variants in MYO15A were the most reported and accounted for 102 out of 420 (24.3\%) mutant alleles (Table S5). 


\section{Mitochondrial DNA variants}

The analysis of the retrieved records has shown that mitochondria HI was mainly reported in three African sub-populations. Except for a few studies from Cameroon (Trotta et al. 2011), Nigeria (Lasisi et al. 2014), and South Africa (Bardien et al. 2009); the remaining two reports were from North Africa (Table S6). The m.1555A $>$ G variant was the most frequently associated mitochondrial variant found in two out of the three countries, Tunisia (Mkaouar-Rebai et al. 2010; Souissi et al. 2021) and Morocco (Nahili et al. 2010). However, the reported frequencies of m.1555A $>\mathrm{G}$ variant were less than $2 \%$, indicating the low contribution of the variant to HI in the studies reviewed. Four (4) PLP mitochondrial RNA1 variants (MTRNR1: [1048C $>\mathrm{T} ; 1462 \mathrm{G}>\mathrm{T}$, $1018 \mathrm{G}>\mathrm{A}, 1503 \mathrm{G}>\mathrm{A}]$ ) were found within the Cameroonian population.

\section{Syndromic hearing impairment}

Fourteen (14) publications from five African countries were identified to report on syndromic HI. Ten (10) syndromes were found, and Usher syndrome was the most frequently reported syndrome associated with $\mathrm{HI}$, characterized at the molecular level.

\section{Usher syndrome}

Variants from three known Usher syndrome genes $U S H 2 A, U S H 1 G$, and $U S H 1 C$ were found from the records retrieved. However, $U S H 2 A$ was the most common gene with the highest number of alleles with PLP variants (Table S7). Usher syndrome type 2 was the common type of Usher syndrome found in this review. The patients with Usher syndrome had early onset of severe to profound $\mathrm{HI}$ and a post-pubertal onset of retinitis pigmentosa. Some Usher syndrome patients were found to carry mutations in $M Y O 7 A$, and $P C D H 15$ genes. Among indigenous Black South Africans, MYO7A was identified as the major gene associated with HI, with p.(P1780S) founder variant as the most commonly associated variant (Kabahuma et al. 2021). The medical examination of MYO7A and PCDH15 patients showed that they had Usher syndrome type 1 . These patients reported profound congenital bilateral HI and childhood-onset retinitis pigmentosa resulting in a progressively constricted visual field and night blindness. Fundus examination revealed retinal degeneration in all the patients (Ben-Rebeh et al. 2016). Using WES, a novel $R R M 2 B$ c. $786 \mathrm{G}>\mathrm{T}$ variant was identified, as a plausible disease-causing, in two affected sibling of Afrikaner ancestry, in South Africa, presenting a recessive sensorineural hearing impairment, associated with rod-cone dystrophy and kidney disease; the variant was replicated in two unrelated South African patients with similar clinical phenotype suggesting a founder effect (Roberts et al. 2020).

\section{Distal renal tubular acidosis}

Distal renal tubular acidosis with HI was found to be associated with variants in $A T P 6 V 1 B 1$ gene with a total of 85 reported mutant alleles $(n=85 / 269 ; 31.6 \%)$. A high genetic and allelic heterogeneity was observed from the analysis of the reported variants, in that most variants were reported in only one study (Table S7). Three (3) out of the 50 variants, ATP6V1B1: c. $1155 \mathrm{dupC}:$ p.(I386Hfs*56), ATP6V1B1: c.175-1G >C, and TMC1: c. 100C > T: p. (R34X) were reported in 4,3 , and 2 different studies, respectively, the remaining variants were reported in one study only (Table S7). The analysis of retrieved genes associated with NSHI suggested that ATP6VIBI variants may be localized to only North Africa countries, suggesting a founder effect (Nagara et al. 2014). Variations in the ATP6VIBI gene were reported only from Algeria, Tunisia, and Morocco.

\section{Alström syndrome}

The Alström Syndrome patients belonged to a Tunisian family and ALMS1: c. 10388-2A>G variant was identified as the likely cause of the condition (Chakroun et al. 2016). Two affected family members were examined in this family and found to have progressive vision and hearing loss, pendular nystagmus, and photophobia. Fundus examination of the affected individuals revealed sallow optic discs, attenuated vessels of the posterior poles, and pigment retinal degeneration. The patients had deep-set eyes and flat feet. Systemic/clinical examination did not identify other features such as hepatic dysfunction, abnormal digits, mental retardation, scoliosis, hypertension, renal dysfunction, alopecia, hypothyroidism, type 2 diabetes mellitus, hyperlipidemia, and acanthosis nigricans (Chakroun et al. 2016).

\section{Cockayne syndrome}

A novel splice site variant found in the Cockayne syndrome group A gene (ERCC8: c.551-1G>A) was associated with $\mathrm{HI}$ in two Somali siblings. The patients showed the features of Cockayne syndrome which included skin photosensitivity, progressive ataxia, spasticity, hearing loss, central and peripheral demyelination, and intracranial calcifications (Kleppa et al. 2007). 


\section{H syndrome}

Five Tunisian unrelated patients were suspected to have the rare $\mathrm{H}$ syndrome with a characteristic phenotype of pigmentation and hypertrichosis patches. The other clinical features of $\mathrm{H}$ syndrome consisted of hepatosplenomegaly, hearing loss, heart abnormalities, and hypogonadism. Three SLC29A3 variants [c.42delC: p.(S15Pfs*86), c.1088G >A: p.(R363Q), c.971C > T: p.(P324L)] were found to be associated with the condition (Jaouadi et al. 2018).

\section{Jervell and Lange-Nielsen syndrome}

Jervell and Lange-Nielsen syndrome was found in a Moroccan family that presented with congenital severe bilateral sensorineural HI. The affected patient had several episodes of syncope and was diagnosed with an associated KCNQ1 (c.1343dupC, p.Glu449Argfs*14) variant (Adadi et al. 2017).

\section{Pendred syndrome}

A p.(L445W) variant in the Pendred syndrome (PDS) gene was associated with $\mathrm{HI}$ in Tunisian patients suspected to have Pendred syndrome. The affected patients reported sensorineural or mixed HI and an associated goiter in some cases. All the patients were found to have enlarged bilateral vestibular aqueducts, however, they had normal thyroid hormone levels (Charfeddine et al. 2010).

\section{Keratitis-ichthyosis-deafness syndrome}

An ectodermal defect that consists of an atypical ichthyosiform erythroderma linked to sensorineural deafness is referred to as Keratitis-ichthyosis-deafness (KID) syndrome (OMIM 148210). KID syndrome patients mostly have congenital HI. Two unrelated patients from Cameroon with KID syndrome were reported to have heterozygous GJB2p.D50N mutation (Wonkam et al. 2013).

\section{Discussion}

This review of literature focused on the landscape of genetic causes of HI in Africa, and it is the most comprehensive report, to date. The study suggested that a large majority of African countries are still to be investigated. The few available data using next-generation sequencing reveals expected genetic and allelic heterogeneity, and a high proportion of variants not previously reported (Bakhchane et al. 2015b; Ben-Rebeh et al. 2016; Oluwole et al. 2021; Wonkam et al. 2021b), that will definitively contribute to improving the disease-gene pair curation, globally. Moreover, there is evidence that novel $\mathrm{HI}$ genes will be discovered in Africa, based on the much lower pick-up rate when exploring patients with target genes panels (Lebeko et al. 2015; Yan et al. 2016).

Globally, connexins are the most associated genes to HI (Adadey et al. 2020b; Chan and Chang 2014); however, their contribution to HI in sub-Saharan Africa is negligible (Adadey et al. 2020b; Kabahuma et al. 2011; Wonkam 2015), except for Ghana (Adadey et al. 2019; Hamelmann et al. 2001) and North African (Abidi et al. 2008; Lucotte 2007 ) countries. Indeed, studies investigating the association of connexin gene variants with HI from other sub-Saharan African countries such as Cameroon (Bosch et al. 2014b; Tingang Wonkam et al. 2019), Nigeria (Lasisi et al. 2014), South Africa (Bosch et al. 2014b), Kenya, and Sudan (Gasmelseed et al. 2004) found a very low number of PLP variants in GJB2. The GJB2: 35delG is the most predominant variant in Europe (Adadey et al. 2020b; Gasparini et al. 2000), and the Mediterranean countries including Tunisia, Morocco, Egypt, and Algeria (Lucotte 2007). The GJB2: $35 \mathrm{delG}$ age was estimated at about 10,000-14,000 years ago, and emerged in the Mediterranean (Rothrock et al. 2003; Van Laer et al. 2001), and spread in Europe and Asia through the two Neolithic population movements (Dzhemileva et al. 2010). The other GJB2 PLP variants identified in North Africa were GJB2: c.139G $>$ T: p. $\left(\mathrm{E} 47^{*}\right)$ and c.109G>A: p.(V37I). The GJB2: c.109G >A: p.(V37I) is the most common in Asia, particularly in China (Adadey et al. 2020b). The GJB2: c.427C >T: p.(R143W) variant is the most prevalent variant associated with $\mathrm{HI}$ among Ghanaians (Adadey et al. 2019, 2020a; Brobby et al. 1998; Hamelmann et al. 2001), and was described as a founder variant in Adamorobe (Brobby et al. 1998), a village in the Eastern Region of Ghana. The carrier frequency of the variant among the hearing Ghanaian population was estimated at 1.4\% (Adadey et al. 2019). The GJB2: c.427C > T: p. $(\mathrm{R} 143 \mathrm{~W})$ variant is not exclusive to Ghana and has been found among Americans, likely through the slave trade, and in some Asian populations (Adadey et al. 2020b). Haplotype analysis of hearing-impaired individuals from the Japanese population suggested that the GJB2: c.427C >T: p. (R143W) founder variant occurred as multiple events (Shinagawa et al. 2020). Additional studies in Ghana to estimate the age of this variant is needed.

The current review suggested that non-GJB2 connexins genes do not contribute significantly to $\mathrm{HI}$ in Africa. Though studies from South Africa (Bosch et al. 2014a) and Ghana (Adadey et al. 2020a) reported variants in GJAl and GJB4, almost all the variants were predicted as benign or uncertain significance. A likely pathogenic GJB4 variant was found in a hearing-impaired participant from Ghana (Adadey et al. 2020a). GJB4 protein oligomerizes with other connexins in the cells of the inner ear to form gap junctions for 
the transport of ions across the cell. The expression of the gene in mouse (Bult et al. 2019) and rat (Wang et al. 2010) cochlea provides evidence of its importance in the auditory system. There is a need to sample many other African populations to understand the contribution of the $G J B 4$ to $\mathrm{HI}$.

$M Y O 15 A$ and $A T P 6 V 1 B 1$ genes were the most common non-GJB2 genes with PLP in Africa. MYO15A is an autosomal recessive deafness gene located on the human chromosome 17p11.2. An animal study has shown that the gene is expressed in the inner ear of mice (Kanzaki et al. 2006). It was found in mice that there is an interaction of the C-terminal PDZ domains of MYO15A and WHRN for recruiting endogenous WHRN to the tip stereocilia of hair cells (Belyantseva et al. 2005). ATP6V1B1 is located on chromosome 2 p13.3 of the human genome. According to the Online Mendelian Inheritance in Man (OMIM) database, ATP6VIBI associates with distal renal tubular acidosis 2 with progressive sensorineural hearing loss (MIM 267300) as syndromic phenotype. Studies from Africa reported ATP6V1B1 association with distal renal tubular acidosis patients with sensorineural HI (Boualla et al. 2016; Dahmani et al. 2020; Elhayek et al. 2013). Unlike MYO15A PLP variants that were found in Central and North African countries, ATP6V1B1 variants were reported only in North African countries from Algeria (Dahmani et al. 2020), Tunisia (Elhayek et al. 2013), and Morocco (Boualla et al. 2016). The localization of ATP $6 \mathrm{~V} 1 \mathrm{~B} 1$ variants in North African countries may be due to a founder effect. In addition, the high prevalence of consanguinity within North African populations (El Bouchikhi et al. 2020; Mete et al. 2020) may be the driving force for the spread of ATP6V1B1 variants in these populations. However, the association of $A T P 6 V 1 B 1$ variants with $\mathrm{HI}$ is not exclusive to North Africa, there were reports from other parts of the world including the USA (Subasioglu Uzak et al. 2013), and Japan (Yashima et al. 2010).

Mitochondrial gene variants have been associated with different multisystem syndromes including the nervous system, neuromuscular, and endocrine organs (Finsterer 2020; Mkaouar-Rebai et al. 2013a). We found seven studies from Cameroon (Trotta et al. 2011), Morocco (Nahili et al. 2010), and Tunisia (Mkaouar-Rebai et al. 2006, 2013a, b; Tabebi et al. 2015) that reported mitochondria variants in HI. The mitochondria are known to generate free radicals and reactive oxygen species (ROS) which may result in acoustic trauma when they accumulate in the cochlea (Le Prell et al. 2007; Yan and Liu 2010). Most mitochondria NSHI are caused by mutations in the $12 \mathrm{~S}$ ribosomal RNA and tRNASer (UCN) genes which are maternally inherited (Guan 2004). Our review identified 12S rRNA m.1555A>G mutation as the most prevalent mitochondria variant associated with NSHI. Variable phenotypes such as the age of onset and severity have been reported in patients with the 12S rRNA m.1555A $>$ G variant (Friedman et al. 1999). The phenotypic variability of mitochondria-associated $\mathrm{HI}$ is also sometimes influenced by $G J B 2$ mutations (Yan and Liu 2010). It is therefore important to investigate mitochondria variants in Ghanaian and North African populations towards the understanding and identification of HI gene modifiers in Africa. Owing to the diversity of the African population, it is important to study mitochondria variants in different African populations to understand their contribution to the development of $\mathrm{HI}$.

The outcome of our review showed that Usher syndrome was the most common syndromic HI studied at the molecular level in Africa. Usher syndrome is characterized by $\mathrm{HI}$ and retinitis pigmentosa. Damage to the inner ear that impedes the inner ear functioning is the possible cause of $\mathrm{HI}$ and balance problems in Usher syndrome patients (Möller et al. 1989). According to phenotypic expressions (severity of hearing impairment, age of retinitis pigmentosa onset, and the presence or absence of vestibular response), there are three main types of Usher syndrome, and type 1 is the most severe form (Jaijo et al. 2007). Usher syndrome type 2 was found to be the most common type of Usher syndrome in Africa. Similar to the African observation, type 2 was reported as the main type of the syndrome in Canada (Ebermann et al. 2009). Five genes (USH2A, USH1G, USH1C, MYO7A, and $P C D H 15$ ) were associated with Usher syndrome from Africa. A recent study among Black South Africans identified $M Y O 7 A$ as the most prevalent gene associated with syndromic $\mathrm{HI}$ in the South African population and the founder variant p.(P1780S) was the most implicated variant (Kabahuma et al. 2021).

\section{Expert's comment and perspectives}

Despite the great value provided by this review, there are indications that the results do not represent the full extent of HI genes in Africa. First, the genetics of HI is yet to be studied in most sub-Saharan African countries. Second, some studies excluded reported on known syndromic conditions with $\mathrm{HI}$ and did not investigate them at the molecular level. Indeed there are clinical reports suggesting that Waardenburg syndrome is the most common syndromic HI in numerous sub-Saharan African populations (Adadey et al. 2019; Tingang Wonkam et al. 2019); however, no report on the genetics of this condition was found in the literature. Third, less than $20 \%$ of studies used next-generation sequencing (with none using Whole-Genome Sequencing), which means that a fair number of genes and variants have not been investigated, owing to the high genetic and allelic heterogeneity of HI. Finally, almost all the studies reviewed focused on childhood HI (except for two), meaning that genes associated with adult HI still need to be uncovered in Africa. Therefore, the data provided by the present review have some limitations in its usability to design and develop 
a single diagnostic approach for screening $\mathrm{HI}$ in all parts of the continent. To address this challenge: there is a need to systematically investigate more African populations, using multiplex families, and next-generation sequencing (WES and WGS) to identify novel genes and their associated variants towards the development of population-specific diagnostic approaches. This would be facilitated by a high fertility rate in most of Africa, and a high consanguinity rate in some parts of Africa.

\section{Conclusion}

This review provides the most comprehensive data on HI gene variants and emphasizes that most African populations are largely under-investigated, with reports only found in nearly a third of African countries. GJB2 appeared to be the most investigated HI gene on the continent, yet its contribution to the burden of the disease was negligible in most sub-Saharan African populations, but for those from North Africa where GJB2-35delG, p.(E47*) and p.(V37I) were predominantly found, and Ghana where high frequency of the GJB2-p.(R143W) founder variant was reported. $M Y O 15 A$ was the second frequently reported gene associated with NSHI in both North and Central Africa. ATP6VIBI variants were associated with distal renal tubular acidosis patients with sensorineural $\mathrm{HI}$ and only reported from North Africa. Usher syndrome was the most common syndromic HI genetically investigated.

The poor investigation of the genetics of $\mathrm{HI}$ in most African populations, and the limited use of WES for the available data suggested that the current report is likely an underestimation of the real spectrum of genes and variants associated with HI among Africans, considering the high heterogeneity of $\mathrm{HI}$ and the genetic diversity in Africa. The present review provides evidence that African populations are important in the discovery of the next sets of novel HI genes, this is further favored by the high fertility and consanguinity rates in some Africa regions and will contribute to improving our understanding of HI pathobiology, globally.

Supplementary Information The online version contains supplementary material available at https://doi.org/10.1007/s00439-021-02376-y.

Author contributions Conceptualization, AW, GAA, OQ, and SMA; methodology, SMA, EWT, and ETA; formal analysis, SMA, and EWT; writing — original draft preparation, SMA, EWT, AW; writing—review and editing, SMA, EWTS, ETA, OQ, GAA, and AW; supervision, AW, GAA, and OQ; funding acquisition, AW, and GAA. All authors have read and agreed to the published version of the manuscript.

Funding This work was supported by funds from the World Bank African Centres of Excellence grant (ACE02-WACCBIP: Awandare) and a DELTAS Africa grant (DEL-15-007: Awandare). The DELTAS Africa Initiative is an independent funding scheme of the African
Academy of Sciences (AAS)'s Alliance for Accelerating Excellence in Science in Africa (AESA) and supported by the New Partnership for Africa's Development Planning and Coordinating Agency (NEPAD Agency) with funding from the Wellcome Trust (107755/Z/15/Z: to GAA and AW) and the UK government; the NIH, USA, grant number U01-HG-009716 to AW, and the African Academy of Science/Wellcome Trust, grant number H3A/18/001 to AW. The funders had no role in study design, data collection, and analysis, decision to publish, or preparation of the manuscript.

\section{Declarations}

Conflict of interest The authors declare no conflict of interest.

Open Access This article is licensed under a Creative Commons Attribution 4.0 International License, which permits use, sharing, adaptation, distribution and reproduction in any medium or format, as long as you give appropriate credit to the original author(s) and the source, provide a link to the Creative Commons licence, and indicate if changes were made. The images or other third party material in this article are included in the article's Creative Commons licence, unless indicated otherwise in a credit line to the material. If material is not included in the article's Creative Commons licence and your intended use is not permitted by statutory regulation or exceeds the permitted use, you will need to obtain permission directly from the copyright holder. To view a copy of this licence, visit http://creativecommons.org/licenses/by/4.0/.

\section{References}

Abidi O, Boulouiz R, Nahili H, Bakhouch K, Wakrim L, Rouba H, Chafik A, Hassar M, Barakat A (2008) Carrier frequencies of mutations/polymorphisms in the connexin 26 gene (GJB2) in the Moroccan population. Genet Test 12:569-574. https://doi. org/10.1089/gte.2008.0063

Adadey SM, Manyisa N, Mnika K, de Kock C, Nembaware V, Quaye O, Amedofu GK, Awandare GA, Wonkam A (2019) GJB2 and GJB6 mutations in non-syndromic childhood hearing impairment in Ghana. Front Genet 10:1-8. https://doi.org/10.3389/ fgene.2019.00841

Adadey SM, Esoh KK, Quaye O, Amedofu GK, Awandare GA, Wonkam A (2020a) GJB4 and GJC3 variants in non-syndromic hearing impairment in Ghana. Exp Biol Med 245:1355-1367. https://doi.org/10.1177/1535370220931035

Adadey SM, Wonkam-Tingang E, Twumasi Aboagye E, Nayo-Gyan DW, Boatemaa Ansong M, Quaye O, Awandare GA, Wonkam A (2020b) Connexin genes variants associated with non-syndromic hearing impairment: a systematic review of the global burden. Life 10:1-32. https://doi.org/10.3390/life10110258

Adadey SM, Schrauwen I, Aboagye ET, Bharadwaj T, Esoh KK, Basit S, Acharya A, Nouel-Saied LM, Liaqat K, Wonkam-Tingang E, Mowla S, Awandare GA, Ahmad W, Leal SM, Wonkam A (2021) Further confirmation of the association of SLC12A2 with non-syndromic autosomal-dominant hearing impairment. J Hum Genet. https://doi.org/10.1038/s10038-021-00954-6

Adadi N, Lahrouchi N, Bouhouch R, Fellat I, Amri R, Alders M, Sefiani A, Bezzina C, Ratbi I (2017) Clinical and molecular findings in a Moroccan family with Jervell and Lange-Nielsen syndrome: a case report. J Med Case Rep 11:1-5. https://doi.org/10.1186/ s13256-017-1243-1

Amalou G, Bonnet C, Riahi Z, Bouzidi A, Elrharchi S, Bousfiha A, Charif M, Kandil M, Lenaers G, Petit C (2021) A homozygous $M P Z L 2$ deletion is associated with non syndromic hearing loss 
in a moroccan family. Int J Pediatr Otorhinolaryngol 140:1-4. https://doi.org/10.1016/j.ijporl.2020.110481

Bakhchane A, Charif M, Salime S, Boulouiz R, Nahili H, Roky R, Lenaers G, Barakat A (2015a) Recessive TBC1D24 mutations are frequent in Moroccan non-syndromic hearing loss pedigrees. PLoS One 10:1-6. https://doi.org/10.1371/journal.pone.0138072

Bakhchane A, Charoute H, Nahili H, Roky R, Rouba H, Charif M, Lenaers G, Barakat A (2015b) A novel mutation in the TMC1 gene causes non-syndromic hearing loss in a Moroccan family. Gene 574:28-33. https://doi.org/10.1016/j.gene.2015.07.075

Bardien S, Human H, Harris T, Hefke G, Veikondis R, Schaaf HS, van der Merwe L, Greinwald JH, Fagan J, de Jong G (2009) A rapid method for detection of five known mutations associated with aminoglycoside-induced deafness. BMC Med Genet 10:1-9. https://doi.org/10.1186/1471-2350-10-2

Bayazit YA, Y1lmaz M (2006) An overview of hereditary hearing loss. ORL 68:57-63. https://doi.org/10.1159/000091090

Behlouli A, Bonnet C, Abdi S, Hasbellaoui M, Boudjenah F, Hardelin JP, Louha M, Makrelouf M, Ammar-Khodja F, Zenati A, Petit C (2016) A novel biallelic splice site mutation of TECTA causes moderate to severe hearing impairment in an Algerian family. Int J Pediatr Otorhinolaryngol 87:28-33. https://doi.org/10.1016/j. ijporl.2016.04.040

Belguith H, Aifa-Hmani M, Dhouib H, Said MB, Mosrati MA, Lahmar I, Moalla J, Charfeddine I, Driss N, Arab SB, Ghorbel A, Ayadi H, Masmoudi S (2009) Screening of the DFNB3 locus: identification of three novel mutations of MYO15A associated with hearing loss and further suggestion for two distinctive genes on this locus. Genet Test Mol Biomark 13:147-151. https://doi.org/ $10.1089 / \mathrm{gtmb} .2008 .0077$

Belyantseva IA, Boger ET, Naz S, Frolenkov GI, Sellers JR, Ahmed ZM, Griffith AJ, Friedman TB (2005) Myosin-XVa is required for tip localization of whirlin and differential elongation of haircell stereocilia. Nat Cell Biol 7:148-156. https://doi.org/10.1038/ ncb1219

Ben-Rebeh I, Grati M, Bonnet C, Bouassida W, Hadjamor I, Ayadi H, Ghorbel A, Petit C, Masmoudi S (2016) Genetic analysis of Tunisian families with Usher syndrome type 1: toward improving early molecular diagnosis. Mol vis 22:827-835

Bensaid M, Hmani-Aifa M, Hammami B, Tlili A, Hakim B, Charfeddine I, Ayadi H, Ghorbel A, Castillo ID, Masmoudi S (2011) DFNB66 and DFNB67 loci are non allelic and rarely contribute to autosomal recessive nonsyndromic hearing loss. Eur J Med Genet 54:e565-e569. https://doi.org/10.1016/j.ejmg.2011.07.003

Bosch J, Lebeko K, Nziale JJ, Dandara C, Makubalo N, Wonkam A (2014a) In search of genetic markers for nonsyndromic deafness in Africa: a study in Cameroonians and Black South Africans with the GJB6 and GJAl candidate genes. OMICS 18:481-485. https://doi.org/10.1089/omi.2013.0166

Bosch J, Noubiap JJN, Dandara C, Makubalo N, Wright G, Entfellner J-BD, Tiffin N, Wonkam A (2014b) Sequencing of GJB2 in Cameroonians and Black South Africans and comparison to 1000 genomes project data support need to revise strategy for discovery of nonsyndromic deafness genes in Africans. OMICS 18:705-710. https://doi.org/10.1089/omi.2014.0063

Boualla L, Jdioui W, Soulami K, Ratbi I, Sefiani A (2016) Clinical and molecular findings in three Moroccan families with distal renal tubular acidosis and deafness: report of a novel mutation of ATP6V1B1 gene. Curr Res Transl Med 64:5-8. https://doi.org/ 10.1016/j.retram.2016.01.005

Brobby GW, Müller-Myhsok B, Horstmann RD (1998) Connexin 26 R143W mutation associated with recessive nonsyndromic sensorineural deafness in Africa. N Engl J Med 338:548-550. https:// doi.org/10.1056/NEJM199802193380813
Bult CJ, Blake JA, Smith CL, Kadin JA, Richardson JE (2019) Mouse genome database (MGD) 2019. Nucleic Acids Res Spec Publ 47:D801-D806. https://doi.org/10.1093/nar/gky1056

Campbell MC, Tishkoff SA (2008) African genetic diversity: implications for human demographic history, modern human origins, and complex disease mapping. Annu Rev Genom Hum Genet 9:403-433. https://doi.org/10.1146/annurev.genom.9.081307. 164258

Chakchouk I, Ben Said M, Jbeli F, Benmarzoug R, Loukil S, Smeti I, Chakroun A, Gibriel AA, Ghorbel A, Hadjkacem H, Masmoudi S (2015) NADf chip, a two-color microarray for simultaneous screening of multigene mutations associated with hearing impairment in North African Mediterranean countries. J Mol Diagn 17:155-161. https://doi.org/10.1016/j.jmoldx.2014.11.003

Chakchouk I, Zhang D, Zhang Z, Francioli LC, Santos-Cortez RLP, Schrauwen I, Leal SM (2019) Disparities in discovery of pathogenic variants for autosomal recessive non-syndromic hearing impairment by ancestry. Eur J Hum Genet 27:1456-1465. https:// doi.org/10.1038/s41431-019-0417-2

Chakroun A, Ben Said M, Ennouri A, Achour I, Mnif M, Abid M, Ghorbel A, Marshall JD, Naggert JK, Masmoudi S (2016) Longterm clinical follow-up and molecular testing for diagnosis of the first Tunisian family with Alstrom syndrome. Eur J Med Genet 59:444-451. https://doi.org/10.1016/j.ejmg.2016.08.004

Chan DK, Chang KW (2014) GJB2-associated hearing loss: systematic review of worldwide prevalence, genotype, and auditory phenotype. Laryngoscope 124:E34-E53. https://doi.org/10.1002/lary. 24332

Charfeddine I, Mnejja M, Hammami B, Chakroun A, Masmoudi S, Ayadi H, Ghorbel A (2010) Pendred syndrome in Tunisia. Eur Ann Otorhinolaryngol Head Neck Dis 127:7-10. https://doi.org/ 10.1016/j.anorl.2010.02.002

Chiereghin C, Robusto M, Mauri L, Primignani P, Castorina P, Ambrosetti U, Duga S, Asselta R, Solda G (2021) SLC22A4 gene in hereditary non-syndromic hearing loss: recurrence and incomplete penetrance of the p.C113Y mutation in Northwest Africa Front Genet 12:1-9. https://doi.org/10.3389/fgene.2021.606630

Dahmani M, Talbi S, Ammar-Khodja F, Ouhab S, Boudjenah F, Djebbar M, Bonnet C, Petit C (2020) ATP6V1B1 recurrent mutations in Algerian deaf patients associated with renal tubular acidosis. Int J Pediatr Otorhinolaryngol 129:1-5. https://doi.org/10.1016/j. ijporl.2019.109772

Duman D, Tekin M (2012) Autosomal recessive nonsyndromic deafness genes: a review. Front Biosci 17:2213-2236. https://doi. org/10.2741/4046

Dzhemileva LU, Barashkov NA, Posukh OL, Khusainova RI, Akhmetova VL, Kutuev IA, Gilyazova IR, Tadinova VN, Fedorova SA, Khidiyatova IM (2010) Carrier frequency of GJB2 gene mutations c.35delG, c.235delC and c.167delT among the populations of Eurasia. J Hum Genet 55:749-754. https://doi.org/10.1038/ jhg.2010.101

Ebermann I, Walger M, Scholl HP, Charbel Issa P, Luke C, Nurnberg G, Lang-Roth R, Becker C, Nurnberg P, Bolz HJ (2007) Truncating mutation of the DFNB59 gene causes cochlear hearing impairment and central vestibular dysfunction. Hum Mutat 28:571-577. https://doi.org/10.1002/humu.20478

Ebermann I, Koenekoop RK, Lopez I, Bou-Khzam L, Pigeon R, Bolz HJ (2009) An USH2A founder mutation is the major cause of Usher syndrome type 2 in Canadians of French origin and confirms common roots of Quebecois and Acadians. Eur J Hum Genet 17:80-84. https://doi.org/10.1038/ejhg.2008.143

El Bouchikhi I, Bouguenouch L, Moufid FZ, Samri I, Abdouss F, Melhouf MA, Houssaini MI, Belhassan K, Atmani S, Ouldim K (2020) Molecular and environmental characterization of Noonan 
syndrome in Morocco reveals a significant association with consanguinity and advanced parental age. Egypt J Med Hum Genet 21:1-9. https://doi.org/10.1186/s43042-020-0047-9

Elhayek D, Perez de Nanclares G, Chouchane S, Hamami S, Mlika A, Troudi M, Leban N, Ben Romdane W, Gueddiche MN, El Amri F, Mrabet S, Ben Chibani J, Castano L, Haj Khelil A, Ariceta G (2013) Molecular diagnosis of distal renal tubular acidosis in Tunisian patients: proposed algorithm for Northern Africa populations for the ATP6V1B1, ATP6VOA4 and SCL4A1 genes. BMC Med Genet 14:119. https://doi.org/10.1186/1471-2350-14-119

Finsterer J (2020) Variant m.1555A $>\mathrm{G}$ in $M T-R N R 1$ causes hearing loss and multiorgan mitochondrial disorder. Medicine. https:// doi.org/10.1097/MD.0000000000018488

Friedman RA, Bykhovskaya Y, Sue CM, DiMauro S, Bradley R, FallisCunningham R, Paradies N, Pensak ML, Smith RJ, Groden J (1999) Maternally inherited nonsyndromic hearing loss. Am J Med Genet 84:369-372. https://doi.org/10.1002/(sici)10968628(19990604)84:4\%3c369::aid-ajmg12\%3e3.0.co;2-v

Gasmelseed NM, Schmidt M, Magzoub MM, Macharia M, Elmustafa OM, Ototo B, Winkler E, Ruge G, Horstmann RD, Meyer CG (2004) Low frequency of deafness-associated $G J B 2$ variants in Kenya and Sudan and novel GJB2 variants. Hum Mutat 23:206207. https://doi.org/10.1002/humu.9216

Gasparini P, Rabionet R, Barbujani G, Melchionda S, Petersen M, Brøndum-Nielsen K, Metspalu A, Oitmaa E, Pisano M, Fortina $P$ (2000) High carrier frequency of the 35delG deafness mutation in European populations. Eur J Hum Genet 8:19-23. https://doi. org/10.1038/sj.ejhg.5200406

Guan M-X (2004) Molecular pathogenetic mechanism of maternally inherited deafness. In: Mitochondrial pathogenesis. Springer, Berlin, pp 259-271

Hamelmann C, Amedofu GK, Albrecht K, Muntau B, Gelhaus A, Brobby GW, Horstmann RD (2001) Pattern of connexin 26 (GJB2) mutations causing sensorineural hearing impairment in Ghana. Hum Mutat 18:84-85. https://doi.org/10.1002/humu. 1156

Hoy D, Brooks P, Woolf A, Blyth F, March L, Bain C, Baker P, Smith E, Buchbinder R (2012) Assessing risk of bias in prevalence studies: modification of an existing tool and evidence of interrater agreement. J Clin Epidemiol 65:934-939. https://doi. org/10.1016/j.jclinepi.2011.11.014

Jaijo T, Aller E, Beneyto M, Najera C, Graziano C, Turchetti D, Seri M, Ayuso C, Baiget M, Moreno F (2007) MYO7A mutation screening in Usher syndrome type I patients from diverse origins. J Med Genet 44:e71-e76. https://doi.org/10.1136/jmg. 2006.045377

Jaouadi H, Zaouak A, Sellami K, Messaoud O, Chargui M, Hammami H, Jones M, Jouini R, Chadli Debbiche A, Chraiet K, Fenniche S, Mrad R, Mokni M, Turki H, Benkhalifa R, Abdelhak S (2018) H syndrome: clinical, histological and genetic investigation in Tunisian patients. J Dermatol 45:978-985. https://doi.org/10.1111/1346-8138.14359

Kabahuma RI, Ouyang X, Du LL, Yan D, Hutchin T, Ramsay M, Penn C, Liu XZ (2011) Absence of GJB2 gene mutations, the GJB6 deletion (GJB6-D13S1830) and four common mitochondrial mutations in nonsyndromic genetic hearing loss in a South African population. Int J Pediatr Otorhinolaryngol 75:611-617. https://doi.org/10.1016/j.ijporl.2011.01.029

Kabahuma RI, Schubert WD, Labuschagne C, Yan D, Blanton SH, Pepper MS, Liu XZ (2021) Spectrum of MYO7A mutations in an indigenous South African population further elucidates the nonsyndromic autosomal recessive phenotype of DFNB2 to include both homozygous and compound heterozygous mutations. Genes 12:274. https://doi.org/10.3390/genes12020274

Kanzaki S, Beyer L, Karolyi IJ, Dolan DF, Fang Q, Probst FJ, Camper SA, Raphael Y (2006) Transgene correction maintains normal cochlear structure and function in 6-month-old Myo15a mutant mice. Hear Res 214:37-44. https://doi.org/10.1016/j. heares.2006.01.017

Kleppa L, Kanavin OJ, Klungland A, Stromme P (2007) A novel splice site mutation in the Cockayne syndrome group A gene in two siblings with Cockayne syndrome. Neuroscience 145:1397-1406. https://doi.org/10.1016/j.neuroscience.2006. 09.025

Kopanos C, Tsiolkas V, Kouris A, Chapple CE, Albarca Aguilera M, Meyer R, Massouras A (2019) VarSome: the human genomic variant search engine. Bioinformatics 35:1978-1980. https://doi. org/10.1093/bioinformatics/bty897

Landrum MJ, Chitipiralla S, Brown GR, Chen C, Gu B, Hart J, Hoffman D, Jang W, Kaur K, Liu C (2020) ClinVar: improvements to accessing data. Nucleic Acids Res 48:D835-D844. https://doi. org/10.1093/nar/gkz972

Lasisi AO, Bademci G, Foster J II, Blanton S, Tekin M (2014) Common genes for non-syndromic deafness are uncommon in subSaharan Africa: a report from Nigeria. Int J Pediatr Otorhinolaryngol 78:1870-1873. https://doi.org/10.1016/j.ijporl.2014. 08.014

Lebeko K, Bosch J, Noubiap JJN, Dandara C, Wonkam A (2015) Genetics of hearing loss in Africans: use of next generation sequencing is the best way forward. Pan Afr Med J. https://doi. org/10.11604/pamj.2015.20.383.5230

Lebeko K, Sloan-Heggen CM, Noubiap JJ, Dandara C, Kolbe DL, Ephraim SS, Booth KT, Azaiez H, Santos-Cortez RL, Leal SM, Smith RJ, Wonkam A (2016) Targeted genomic enrichment and massively parallel sequencing identifies novel nonsyndromic hearing impairment pathogenic variants in Cameroonian families. Clin Genet 90:288-290. https://doi.org/10.1111/cge.12799

Lebeko K, Manyisa N, Chimusa ER, Mulder N, Dandara C, Wonkam A (2017) A genomic and protein-protein interaction analyses of nonsyndromic hearing impairment in Cameroon using targeted genomic enrichment and massively parallel sequencing. OMICS 21:90-99. https://doi.org/10.1089/omi.2016.0171

Le Prell CG, Yamashita D, Minami SB, Yamasoba T, Miller JM (2007) Mechanisms of noise-induced hearing loss indicate multiple methods of prevention. Hear Res 226:22-43. https:// doi.org/10.1016/j.heares.2006.10.006

Li Q, Wang K (2017) InterVar: clinical interpretation of genetic variants by the 2015 ACMG-AMP guidelines. Am J Hum Genet 100:267-280. https://doi.org/10.1016/j.ajhg.2017.01.004

Lucotte G (2007) High prevalences of carriers of the 35delG mutation of connexin 26 in the Mediterranean area. Int J Pediatr Otorhinolaryngol 71:741-746. https://doi.org/10.1016/j.ijporl. 2007.01.010

Masmoudi S, Antonarakis SE, Schwede T, Ghorbel AM, Gratri M, Pappasavas MP, Drira M, Elgaied-Boulila A, Wattenhofer M, Rossier C, Scott HS, Ayadi H, Guipponi M (2001) Novel missense mutations of TMPRSS3 in two consanguineous Tunisian families with non-syndromic autosomal recessive deafness. Hum Mutat 18:101-108. https://doi.org/10.1002/humu.1159

Mete C, Bossavie L, Giles J, Alderman H (2020) Is consanguinity an impediment to child development? Popul Stud 74:139-159. https://doi.org/10.1080/00324728.2019.1699942

Mkaouar-Rebai E, Tlili A, Masmoudi S, Louhichi N, Charfeddine I, Ben Amor M, Lahmar I, Driss N, Drira M, Ayadi H, Fakhfakh F (2006) Mutational analysis of the mitochondrial 12S rRNA and tRNA ${ }^{\mathrm{Ser}(\mathrm{UCN})}$ genes in Tunisian patients with nonsyndromic hearing loss. Biochem Biophys Res Commun 340:12511258. https://doi.org/10.1016/j.bbrc.2005.12.123

Mkaouar-Rebai E, Fendri-Kriaa N, Louhichi N, Tlili A, Triki C, Ghorbel A, Masmoudi S, Fakhfakh F (2010) Whole mitochondrial genome screening in two families with hearing loss: 
detection of a novel mutation in the $12 \mathrm{~S}$ rRNA gene. Biosci Rep 30:405-411. https://doi.org/10.1042/BSR20090120

Mkaouar-Rebai E, Chamkha I, Kammoun T, Alila-Fersi O, Aloulou H, Hachicha M, Fakhfakh F (2013a) A novel MT-CO1 m. $6498 \mathrm{C}>\mathrm{A}$ variation associated with the $\mathrm{m} .7444 \mathrm{G}>\mathrm{A}$ mutation in the mitochondrial COI/tRNA(Ser(UCN)) genes in a patient with hearing impairment, diabetes and congenital visual loss. Biochem Biophys Res Commun 430:585-591. https:// doi.org/10.1016/j.bbrc.2012.11.109

Mkaouar-Rebai E, Chamkha I, Mezghani N, Ben Ayed I, Fakhfakh F (2013b) Screening of mitochondrial mutations in Tunisian patients with mitochondrial disorders: an overview study. Mitochondrial DNA 24:163-178. https://doi.org/10.3109/ 19401736.2012.748045

Möller CG, Ödkvist LM, Kimberling WJ, Davenport SL, Priluck I, White V, Biscone-Halterman K, Brookhouser PE, Lund G, Grissom TJ (1989) Usher syndrome: an otoneurologic study. Laryngoscope 99:73-79. https://doi.org/10.1288/00005537198901000-00014

Mulwafu W, Kuper H, Ensink R (2016) Prevalence and causes of hearing impairment in Africa. Trop Med Int Health 21:158165. https://doi.org/10.1111/tmi.12640

Nagara M, Voskarides K, Nouira S, Ben Halim N, Kefi R, Aloulou H, Romdhane L, Ben Abdallah R, Ben Rhouma F, Aissa K, Boughamoura L, Kammoun T, Azzouz H, Abroug S, Ben Turkia H, Ayadi A, Mrad R, Chabchoub I, Hachicha M, Chemli J, Deltas C, Abdelhak S (2014) Molecular investigation of distal renal tubular acidosis in Tunisia, evidence for founder mutations. Genet Test Mol Biomark 18:741-748. https://doi.org/10. 1089/gtmb.2014.0175

Nahili H, Charif M, Boulouiz R, Bounaceur S, Benrahma H, Abidi O, Chafik A, Rouba H, Kandil M, Barakat A (2010) Prevalence of the mitochondrial A $1555 \mathrm{G}$ mutation in Moroccan patients with non-syndromic hearing loss. Int J Pediatr Otorhinolaryngol 74:1071-1074. https://doi.org/10.1016/j.ijporl.2010.06.008

Olusanya BO, Neumann KJ, Saunders JE (2014) The global burden of disabling hearing impairment: a call to action. Bull World Health Organ 92:367-373. https://doi.org/10.2471/BLT.13. 128728

Oluwole OG, Esoh KK, Wonkam-Tingang E, Manyisa N, Noubiap JJ, Chimusa ER, Wonkam A (2021) Whole exome sequencing identifies rare coding variants in novel human-mouse ortholog genes in African individuals diagnosed with non-syndromic hearing impairment. Exp Biol Med 246:197-206. https://doi.org/10. $1177 / 1535370220960388$

Reed FA, Tishkoff SA (2006) African human diversity, origins and migrations. Curr Opin Genet 16:597-605. https://doi.org/10. 1016/j.gde.2006.10.008

Roberts L, Julius S, Dawlat S, Yildiz S, Rebello G, Meldau S, Pillay K, Esterhuizen A, Vorster A, Benefeld G, da Rocha J, Beighton P, Sellars SL, Thandrayen K, Pettifor JM, Ramesar RS (2020) Renal dysfunction, rod-cone dystrophy, and sensorineural hearing loss caused by a mutation in RRM2B. Hum Mutat 41:1871-1876. https://doi.org/10.1002/humu.24094

Rothrock CR, Murgia A, Sartorato EL, Leonardi E, Wei S, Lebeis SL, Laura EY, Elfenbein JL, Fisher RA, Friderici KH (2003) Connexin 26 35delG does not represent a mutational hotspot. Hum Genet 113:18-23. https://doi.org/10.1007/s00439-003-0944-2

Shearer AE, Hildebrand MS, Smith RJ (2017) Hereditary hearing loss and deafness overview. GeneReviews ${ }^{\circledR}$ [Internet]. https://www. ncbi.nlm.nih.gov/books/NBK1434/

Shinagawa J, Moteki H, Nishio S-y, Noguchi Y, Usami S-i (2020) Haplotype analysis of GJB2 mutations: founder effect or mutational hot spot? Genes 11:250. https://doi.org/10.3390/genes11030250

Sloan-Heggen CM, Bierer AO, Shearer AE, Kolbe DL, Nishimura CJ, Frees KL, Ephraim SS, Shibata SB, Booth KT, Campbell CA
(2016) Comprehensive genetic testing in the clinical evaluation of 1119 patients with hearing loss. Hum Genet 135:441-450. https://doi.org/10.1007/s00439-016-1648-8

Smith RJ, Bale JF Jr, White KR (2005) Sensorineural hearing loss in children. Lancet 365:879-890. https://doi.org/10.1016/S01406736(05)71047-3

Sohani Z, Sarma S, Alyass A, De Souza R, Robiou-du-Pont S, Li A, Mayhew A, Yazdi F, Reddon H, Lamri A (2016) Empirical evaluation of the Q-Genie tool: a protocol for assessment of effectiveness. BMJ Open 6:1-7. https://doi.org/10.1136/bmjop en-2015-010403

Souissi A, Said MB, Ayed IB, Elloumi I, Bouzid A, Mosrati MA, Hasnaoui M, Belcadhi M, Idriss N, Kamoun H (2021) Novel pathogenic mutations and further evidence for clinical relevance of genes and variants causing hearing impairment in Tunisian population. J Adv Res 31:13-24. https://doi.org/10.1016/j.jare. 2021.01.005

Subasioglu Uzak A, Cakar N, Comak E, Yalcinkaya F, Tekin M (2013) ATP6V1B1 mutations in distal renal tubular acidosis and sensorineural hearing loss: clinical and genetic spectrum of five families. Ren Fail 35:1281-1284. https://doi.org/10.3109/0886022X. 2013.824362

Tabebi M, Mkaouar-Rebai E, Mnif M, Kallabi F, Ben Mahmoud A, Ben Saad W, Charfi N, Keskes-Ammar L, Kamoun H, Abid M, Fakhfakh F (2015) A novel mutation MT-COIII m.9267G $>$ C and MT-COI m.5913G > A mutation in mitochondrial genes in a Tunisian family with maternally inherited diabetes and deafness (MIDD) associated with severe nephropathy. Biochem Biophys Res Commun 459:353-360. https://doi.org/10.1016/j.bbrc.2015. 01.151

Talbi S, Bonnet C, Riahi Z, Boudjenah F, Dahmani M, Hardelin JP, Wong Jun Tai F, Louha M, Ammar-Khodja F, Petit C (2018) Genetic heterogeneity of congenital hearing impairment in Algerians from the Ghardaia province. Int J Pediatr Otorhinolaryngol 112:1-5. https://doi.org/10.1016/j.ijporl.2018.06.012

Tingang Wonkam E, Chimusa E, Noubiap JJ, Adadey SM, Fokouo JVF, Wonkam A (2019) GJB2 and GJB6 mutations in hereditary recessive non-syndromic hearing impairment in Cameroon. Genes 10:844. https://doi.org/10.3390/genes10110844

Tlili A, Charfedine I, Lahmar I, Benzina Z, Mohamed BA, Weil D, Idriss N, Drira M, Masmoudi S, Ayadi H (2005) Identification of a novel frameshift mutation in the DFNB31/WHRN gene in a Tunisian consanguineous family with hereditary non-syndromic recessive hearing loss. Hum Mutat 25:503. https://doi.org/10. 1002/humu.9333

Tlili A, Rebeh IB, Aifa-Hmani M, Dhouib H, Moalla J, Tlili-Chouchene J, Said MB, Lahmar I, Benzina Z, Charfedine I, Driss N, Ghorbel A, Ayadi H, Masmoudi S (2008) TMC1 but not TMC2 is responsible for autosomal recessive nonsyndromic hearing impairment in Tunisian families. Audiol Neurootol 13:213-218. https://doi. org/10.1159/000115430

Trotta L, Iacona E, Primignani P, Castorina P, Radaelli C, Del Bo L, Coviello D, Ambrosetti U (2011) GJB2 and MTRNR1 contributions in children with hearing impairment from Northern Cameroon. Int J Audiol 50:133-138. https://doi.org/10.3109/14992 027.2010 .537377

Van Camp G, Smith RJ (2006) Hereditary hearing loss homepage. https://hereditaryhearingloss.org/. Accessed July 2021

Van Laer L, Coucke P, Mueller R, Caethoven G, Flothmann K, Prasad $\mathrm{S}$, Chamberlin G, Houseman M, Taylor G, Van de Heyning C (2001) A common founder for the 35delG GJB2gene mutation in connexin 26 hearing impairment. J Med Genet 38:515-518. https://doi.org/10.1136/jmg.38.8.515

Wang W-H, Yang J-J, Lin Y-C, Yang J-T, Li S-Y (2010) Novel expression patterns of connexin 30.3 in adult rat cochlea. Hear Res 265:77-82. https://doi.org/10.1016/j.heares.2010.02.008 
Wonkam A (2015) Letter to the editor regarding "GJB2, GJB6 or GJA1 genes should not be investigated in routine in non syndromic deafness in people of sub-Saharan African descent". Int J Pediatr Otorhinolaryngol 79:632-633. https://doi.org/10.1016/j.ijporl. 2015.01.012

Wonkam A (2021) Sequence three million genomes across Africa. Nature 590:209-211. https://doi.org/10.1038/ d41586-021-00313-7

Wonkam A, Noubiap JJ, Bosch J, Dandara C, Toure GB (2013) Heterozygous p.Asp50Asn mutation in the GJB2 gene in two Cameroonian patients with keratitis-ichthyosis-deafness (KID) syndrome. BMC Med Genet 14:1-6. https://doi.org/10.1186/ 1471-2350-14-81

Wonkam ET, Chimusa E, Noubiap JJ, Adadey SM, Fokouo JVF, Wonkam A (2019) GJB2 and GJB6 mutations in hereditary recessive non-syndromic hearing impairment in Cameroon. Genes. https://doi.org/10.3390/genes10110844

Wonkam A, Lebeko K, Mowla S, Noubiap JJ, Chong M, Pare G (2021a) Whole exome sequencing reveals a biallelic frameshift mutation in GRXCR2 in hearing impairment in Cameroon. Mol Genet Genom Med 9:e1609. https://doi.org/10.1002/mgg3.1609

Wonkam A, Manyisa N, Bope CD, Dandara C, Chimusa ER (2021b) Whole exome sequencing reveals pathogenic variants in $M Y O 3 A$, MYO15A and COL9A3 and differential frequencies in ancestral alleles in hearing impairment genes among individuals from Cameroon. Hum Mol Genet 29:3729-3743. https://doi.org/10. 1093/hmg/ddaa225

Wonkam Tingang E, Noubiap JJ, Fokouo JVF, Oluwole OG, Nguefack S, Chimusa ER, Wonkam A (2020a) Hearing impairment overview in Africa: the case of Cameroon. Genes 11:1-18. https:// doi.org/10.3390/genes11020233

Wonkam-Tingang E, Schrauwen I, Esoh KK, Bharadwaj T, NouelSaied LM, Acharya A, Nasir A, Adadey SM, Mowla S, Leal $\mathrm{SM}$ (2020b) Bi-allelic novel variants in CLIC5 identified in a
Cameroonian multiplex family with non-syndromic hearing impairment. Genes 11:1249. https://doi.org/10.3390/genes11111 249

Wonkam-Tingang E, Schrauwen I, Esoh KK, Bharadwaj T, NouelSaied LM, Acharya A, Nasir A, Leal SM, Wonkam A (2021) A novel variant in $D X M L 2$ gene is associated with autosomal dominant non-syndromic hearing impairment (DFNA71) in a Cameroonian family. Exp Biol Med 246:1524-1532. https://doi. org/10.1177/1535370221999746

Xu J, Nicholson BJ (2013) The role of connexins in ear and skin physiology-functional insights from disease-associated mutations. Biochim Biophys Acta (BBA) Biomembr 1828:167-178. https:// doi.org/10.1016/j.bbamem.2012.06.024

Yan D, Liu X-Z (2010) Modifiers of hearing impairment in humans and mice. Curr Genom 11:269-278. https://doi.org/10.2174/13892 0210791233054

Yan D, Tekin D, Bademci G, Foster J 2nd, Cengiz FB, KannanSundhari A, Guo S, Mittal R, Zou B, Grati M, Kabahuma RI, Kameswaran M, Lasisi TJ, Adedeji WA, Lasisi AO, Menendez I, Herrera M, Carranza C, Maroofian R, Crosby AH, Bensaid M, Masmoudi S, Behnam M, Mojarrad M, Feng Y, Duman D, Mawla AM, Nord AS, Blanton SH, Liu XZ, Tekin M (2016) Spectrum of DNA variants for non-syndromic deafness in a large cohort from multiple continents. Hum Genet 135:953-961. https://doi.org/10.1007/s00439-016-1697-z

Yashima T, Noguchi Y, Kawashima Y, Rai T, Ito T, Kitamura K (2010) Novel ATP6V1B1 mutations in distal renal tubular acidosis and hearing loss. Acta Otolaryngol 130:1002-1008. https://doi.org/ $10.3109 / 00016481003631529$

Publisher's Note Springer Nature remains neutral with regard to jurisdictional claims in published maps and institutional affiliations. 